\title{
Research on Bond Default Reasons: A Case Study of Wintime Energy Co., Ltd.
}

\author{
Hongyun Jiang*, Qiang Li \\ Business School of Guilin University of technology, P.R. China \\ *Corresponding author. Email: 454492334@qq.com
}

\begin{abstract}
Since 2018, in less than five months, there have been 20 bond default events, among which Wintime Energy Co., Ltd. has repeatedly constituted substantial bond default from 2017 to 2019. This paper uses financial index analysis and Zscore model to conduct early warning analysis on the financial risk of Wintime Energy Co., Ltd. It analyzes the reasons for its bond default and puts forward reasonable suggestions on the current bond default phenomenon.
\end{abstract}

Keywords: Bond default, Financial index analysis, Z-score Model.

\section{INTRODUCTION}

Enterprise is the pillar of economic development, which is of great significance to promote social and economic development and give play to social benefits. According to the statistical analysis report of the bond market in 2018, the custody stock of the national bond market reached 76.45 trillion yuan by the end of 2018 . Bond financing has become an important means of external financing because of its low cost of capital and the ability to protect the control of enterprises. At the same time, bond financing also has some disadvantages that cannot be ignored. The most prominent one is that the financial risk is high, and it needs to fulfil the obligation of payment on the due date. Especially for the enterprises with more aggressive debt expansion, it may even make the enterprises go bankrupt. In recent years, there have been frequent default events in the bond market. Since 2018, there have been 20 default events in less than five months. On July 5, 2018, the "17 Yongtai energy CP004" issued by Wintime Energy Co., Ltd. failed to raise the due repayment funds and could not complete the payment, which constituted a default. On July 6 , united credit lowered the long-term credit rating of Yongtai energy from a to $\mathrm{CC}$, with a negative rating outlook. In 2017-2019, Wintime Energy Co., Ltd. repeatedly constituted a substantial default of bonds. Therefore, with the advent of the wave of bond default, we should think deeply about the current situation of bond default, and explore whether the credit rating agencies overestimate the credit rating of bonds when bond issuers issue bonds? What is the reason why the enterprise can't pay the principal and interest when the bond matures? In view of these problems, how should bond issuing enterprises and credit rating agencies deal with them?

Domestic and foreign scholars have conducted indepth research on the analysis methods, causes and

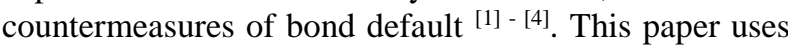
financial index analysis and Z-score Model to conduct early warning analysis on financial risk of Wintime Energy Co., Ltd.. In the analysis of the causes and measures of bond default, few scholars conduct a comprehensive analysis from multiple perspectives. This paper analyses the causes of bond default from four perspectives of macro environment, enterprises themselves, rating agencies and regulatory levels, and puts forward countermeasures. It combines quantitative analysis with qualitative analysis to study the risk of bond default in multiple directions. The research significance of this paper: from the perspective of theoretical significance, credit risk management is an important topic in the capital market; From the perspective of practical significance, this paper analyses the typical facts in the bond default of Wintime Energy Co., Ltd., analyses the credit risk of enterprise bond, and puts forward the improvement scheme and measures to improve the credit risk management of China's bond, which can provide some reference suggestions for the decision-making of credit risk management of China's enterprise bond. 


\section{BOND DEFAULT RISK ASSESSMENT OF WINTIME ENERGY CO., LTD.}

\subsection{Analysis of financial indicators}

The financial situation of Wintime Energy Co., Ltd.in 2013-2017 is analyzed from the following three aspects: solvency, operation ability and profitability:

\subsubsection{Solvency analysis}

The main solvency indicators of Wintime Energy Co., Ltd. from 2013 to 2017 are shown in Table 1.

Table 1 Main solvency indicators of Wintime Energy Co., Ltd. from 2013 to 2017

\begin{tabular}{|c|c|c|c|c|c|c|}
\hline Index & $\begin{array}{l}\text { The main } \\
\text { body }\end{array}$ & 2013 & 2014 & 2015 & 2016 & 2017 \\
\hline \multirow{2}{*}{ Current ratio } & $\begin{array}{l}\text { Wintime } \\
\text { Energy Co., } \\
\text { Ltd. }\end{array}$ & 0.70 & 0.66 & 0.56 & 0.44 & 0.51 \\
\hline & $\begin{array}{l}\text { Industry } \\
\text { average }\end{array}$ & 1.09 & 1.11 & 0.94 & 0.92 & 1.04 \\
\hline \multirow[t]{2}{*}{ Quick ratio } & $\begin{array}{l}\text { Wintime } \\
\text { Energy Co., } \\
\text { Ltd. }\end{array}$ & 0.56 & 0.47 & 0.50 & 0.40 & 0.45 \\
\hline & $\begin{array}{l}\text { Industry } \\
\text { average }\end{array}$ & 0.85 & 0.90 & 0.79 & 0.77 & 0.89 \\
\hline \multirow{2}{*}{ Cash flow liability ratio } & $\begin{array}{l}\text { Wintime } \\
\text { Energy Co., } \\
\text { Ltd. }\end{array}$ & 0.10 & 0.09 & 0.10 & 0.12 & 0.12 \\
\hline & $\begin{array}{l}\text { Industry } \\
\text { average }\end{array}$ & 0.21 & 0.09 & 0.17 & 0.27 & 0.26 \\
\hline \multirow[t]{2}{*}{ Asset liability ratio } & $\begin{array}{l}\text { Wintime } \\
\text { Energy Co., } \\
\text { Ltd. }\end{array}$ & 0.72 & 0.74 & 0.70 & 0.70 & 0.73 \\
\hline & $\begin{array}{l}\text { Industry } \\
\text { average }\end{array}$ & 0.50 & 0.53 & 0.56 & 0.58 & 0.56 \\
\hline \multirow[t]{2}{*}{ Interest cover } & $\begin{array}{l}\text { Wintime } \\
\text { Energy Co., } \\
\text { Ltd. }\end{array}$ & 1.72 & 1.32 & 1.56 & 1.42 & 1.38 \\
\hline & $\begin{array}{l}\text { Industry } \\
\text { average }\end{array}$ & 4.57 & 3.05 & -0.11 & 1.24 & 5.10 \\
\hline
\end{tabular}

Data source: Wintime Energy Co., Ltd.financial statements and tonghuashun website data collation

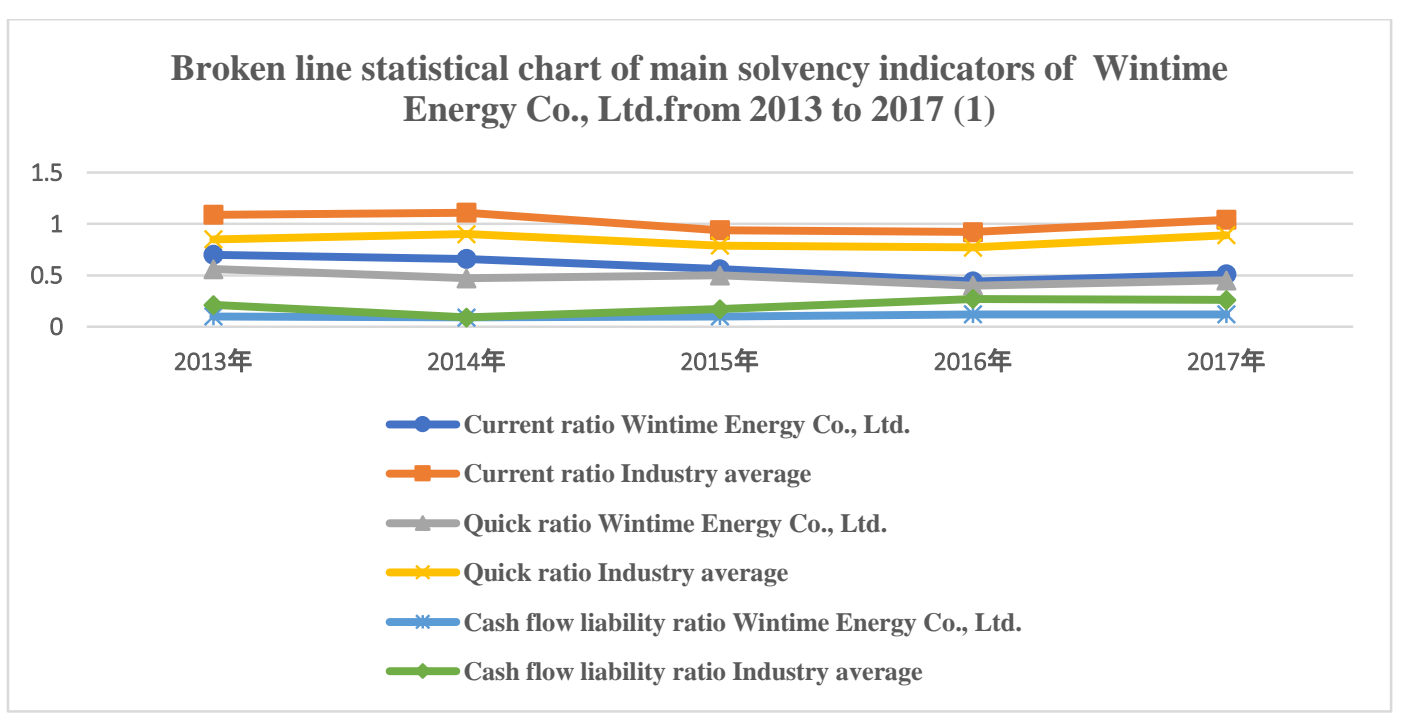

Figure 1 Broken line statistical chart of main solvency indicators of Wintime Energy Co., Ltd. from 2013 to 2017 (1) 


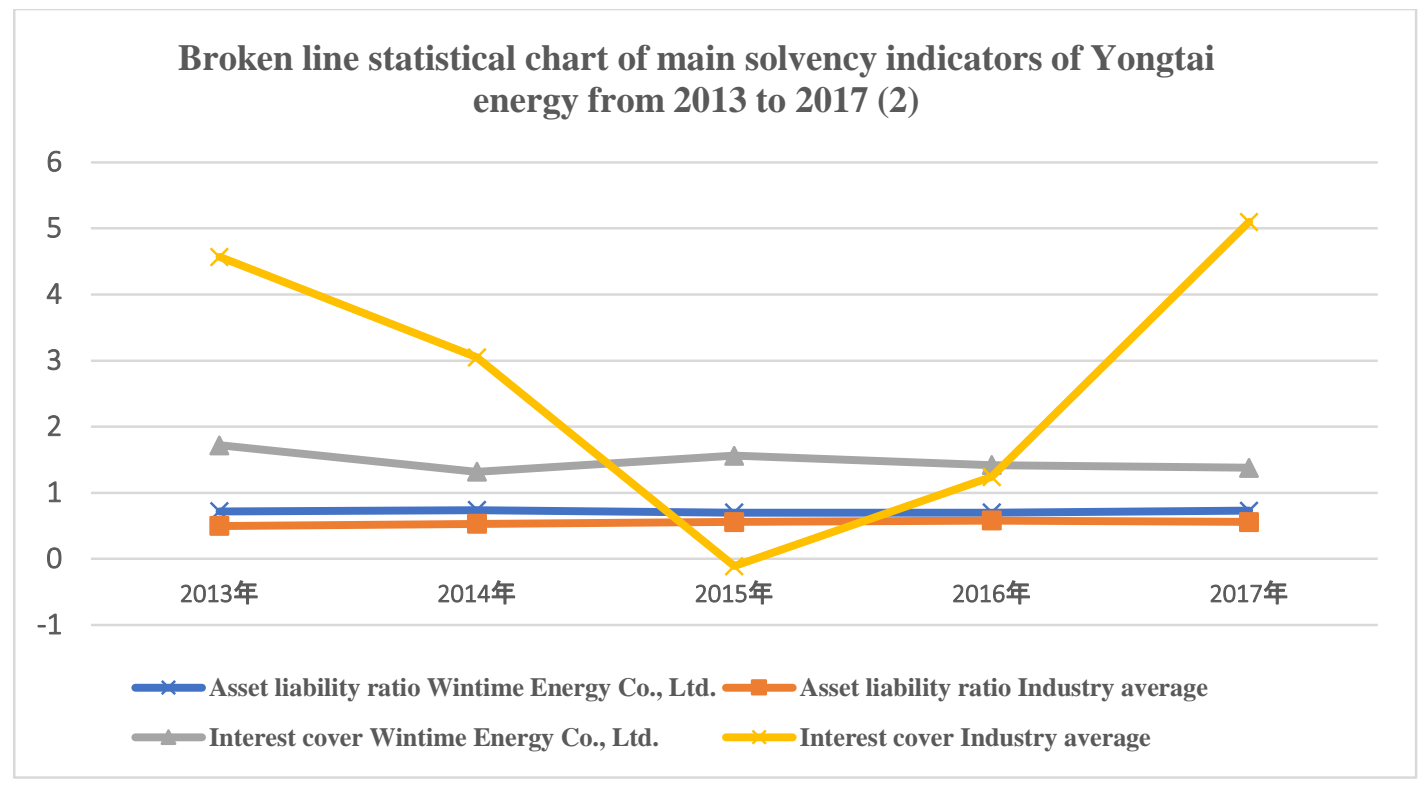

Figure 2 Broken line statistical chart of main solvency indicators of Wintime Energy Co., Ltd. from 2013 to 2017 (2)

In terms of the short-term solvency of Wintime Energy Co., Ltd., the current ratio of Yongtai energy basically showed a downward trend from 2013 to 2017. The current ratio for five consecutive years was lower than the industry average, and the short-term solvency was weak. From 2013 to 2017, the quick ratio of Wintime Energy Co., Ltd. basically maintained at around 0.50 , and the quick ratio for five consecutive years was significantly lower than the industry average, indicating that the degree of guarantee for enterprises to repay shortterm debts when due is low.

In terms of long-term solvency, the asset liability ratio of Wintime Energy Co., Ltd. in 2013-2017 was more than 0.7 , which was higher than the industry average. This shows that Wintime Energy Co., Ltd. has poor long-term solvency compared with the same industry. The interest protection ratio of Wintime Energy Co., Ltd.from 2013 to 2017 shows a downward trend, which indicates that the solvency of the enterprise is weakening, and it is basically lower than the average value of the same industry except for 2015, which indicates that the profitability of Wintime Energy Co., Ltd. is also weaker than that of the same industry, and it has greater solvency risk in the face of the high debt of the enterprise.

\subsubsection{Operation capability analysis}

The main operating capacity indicators of Wintime Energy Co., Ltd. from 2013 to 2017 are as follows:

Table 2 Main operating capacity indicators of Wintime Energy Co., Ltd.from 2013 to 2017

\begin{tabular}{|c|c|c|c|c|c|c|}
\hline Index & The main body & 2013 & 2014 & 2015 & 2016 & 2017 \\
\hline \multirow{2}{*}{ Inventory turnover } & Wintime Energy Co., Ltd. & 16.61 & 9.46 & 15.01 & 26.01 & 33.23 \\
\hline & Industry average & 17.16 & 15.28 & 12.60 & 13.14 & 16.27 \\
\hline \multirow{2}{*}{$\begin{array}{l}\text { Turnover times of accounts } \\
\text { receivable }\end{array}$} & Wintime Energy Co., Ltd. & 4.28 & 2.44 & 2.61 & 3.31 & 5.96 \\
\hline & Industry average & 26.75 & 15.86 & 8.48 & 8.33 & 12.42 \\
\hline \multirow{2}{*}{$\begin{array}{l}\text { Turnover times of current } \\
\text { assets }\end{array}$} & Wintime Energy Co., Ltd. & 0.69 & 0.56 & 0.74 & 0.90 & 1.27 \\
\hline & Industry average & 2.05 & 1.70 & 1.24 & 1.24 & 1.55 \\
\hline \multirow{2}{*}{ Turnover times of fixed assets } & Wintime Energy Co., Ltd. & 1.79 & 1.29 & 0.85 & 0.71 & 0.99 \\
\hline & Industry average & 2.47 & 1.96 & 1.38 & 1.33 & 1.62 \\
\hline \multirow{2}{*}{ Total assets turnover } & Wintime Energy Co., Ltd. & 0.22 & 0.16 & 0.15 & 0.15 & 0.22 \\
\hline & Industry average & 0.72 & 0.56 & 0.40 & 0.40 & 0.51 \\
\hline
\end{tabular}

Data source: Wintime Energy Co., Ltd.financial statements and tonghuashun website data collation 


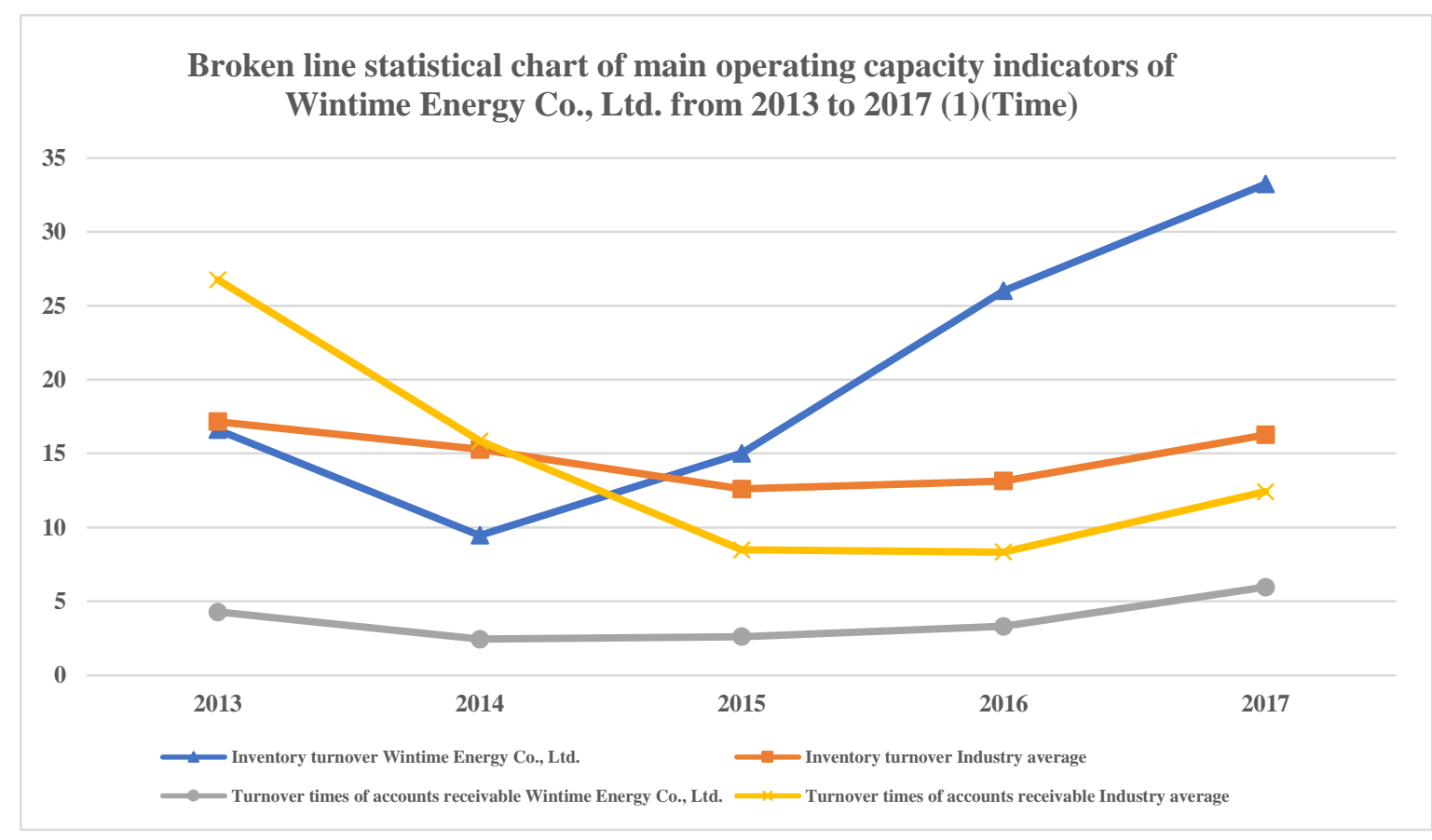

Figure 3 Broken line statistical chart of main operating capacity indicators of Wintime Energy Co., Ltd. from 2013 to 2017 (1) (Times)

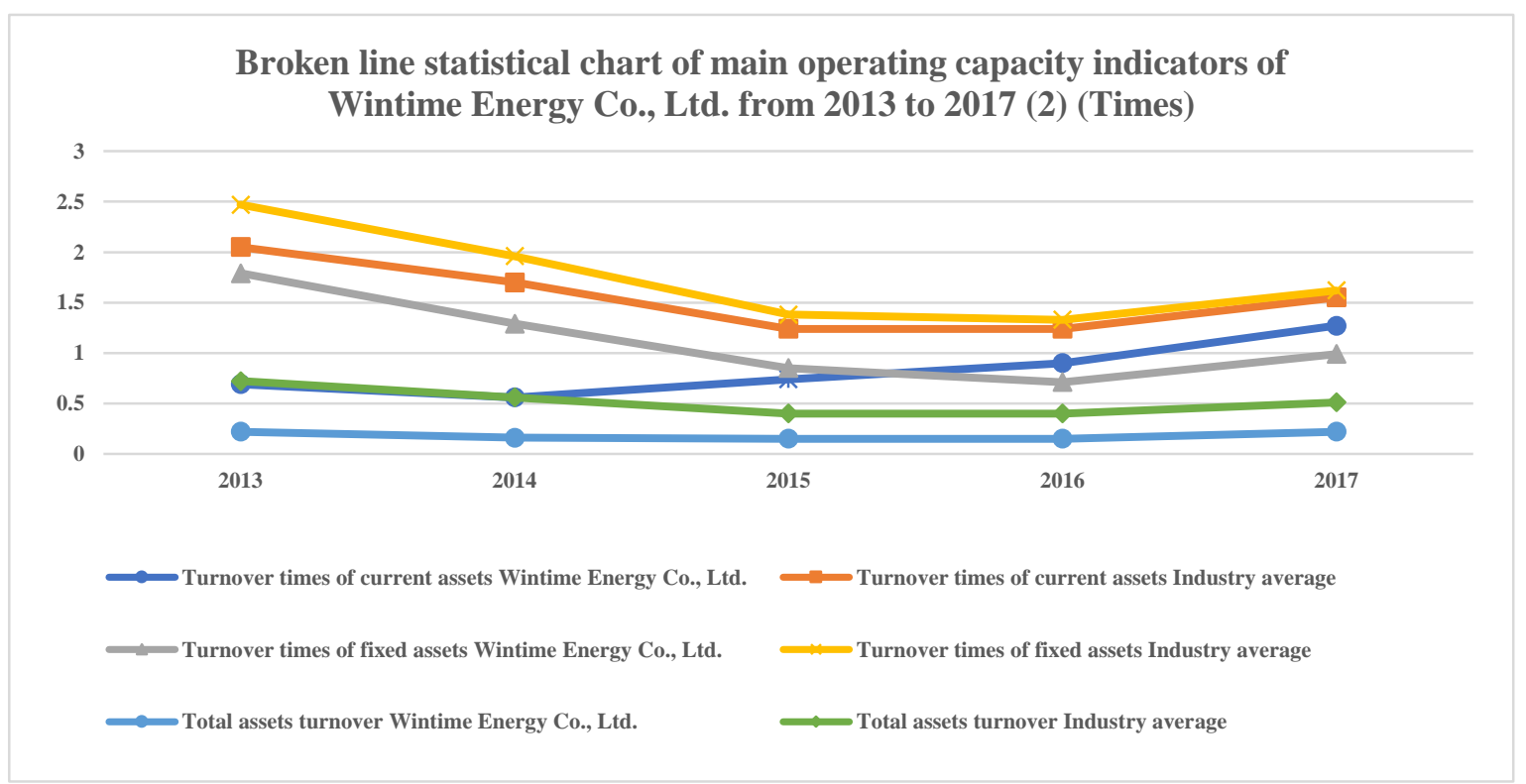

Figure 4 Broken line statistical chart of main operating capacity indicators of Wintime Energy Co., Ltd. from 2013 to 2017 (2) (Times)

From 2013 to 2017, the total assets turnover times of Wintime Energy Co., Ltd. fluctuated between 0.15 and 0.22 times, with the highest value of only 0.22 times, lower than the lowest average of 0.40 times in the same industry, which indicates that the assets efficiency of Wintime Energy Co., Ltd is lower than that in the same industry. In terms of inventory turnover times, inventory turnover times ofWintime Energy Co., Ltd.fluctuated greatly from 2013 to 2017 , with the lowest value of 9.46 times in 2014 and the highest value of 33.23 times in 2017, indicating that inventory turnover rate of Wintime
Energy Co., Ltd.was relatively unstable. In terms of the turnover times of accounts receivable, the turnover times of accounts receivable of Wintime Energy Co., Ltd. from 2013 to 2017 were all below 6 times, which were lower than the industry average. This shows that Wintime Energy Co., Ltd. accounts receivable liquidity is weak, accounts receivable management level is not high. 


\subsubsection{Profitability analysis}

The main profitability indicators of Wintime Energy Co., Ltd. from 2013 to 2017 are as follows:

Table 3 Main profitability indicators of Wintime Energy Co., Ltd. from 2013 to 2017

\begin{tabular}{l|l|c|c|c|c|c}
\hline Index & The main body & 2013 & 2014 & 2015 & 2016 & 2017 \\
\hline \multirow{3}{*}{ Operating profit margin } & Wintime Energy Co., Ltd. & 8.93 & 5.28 & 9.43 & 6.48 & 5.09 \\
\cline { 2 - 7 } & Industry average & 6.92 & 2.08 & -5.94 & -0.56 & 10.38 \\
\hline \multirow{2}{*}{ Net profit rate of sales } & Wintime Energy Co., Ltd. & 6.38 & 6.12 & 9.13 & 5.59 & 3.87 \\
\cline { 2 - 7 } & Industry average & 5.94 & 2.88 & -5.65 & -0.74 & 9.37 \\
\hline \multirow{2}{*}{ Gross profit rate } & Wintime Energy Co., Ltd. & 31.32 & 40.67 & 44.37 & 32.62 & 28.03 \\
\cline { 2 - 7 } & Industry average & 25.01 & 23.10 & 19.44 & 25.76 & 32.72 \\
\hline
\end{tabular}

Data source: Wintime Energy Co., Ltd.financial statements and tonghuashun website data collation

\section{Broken line statistical chart of main profitability indicators of Wintime Energy Co., Ltd. from 2013 to 2017 (1) (\%)}

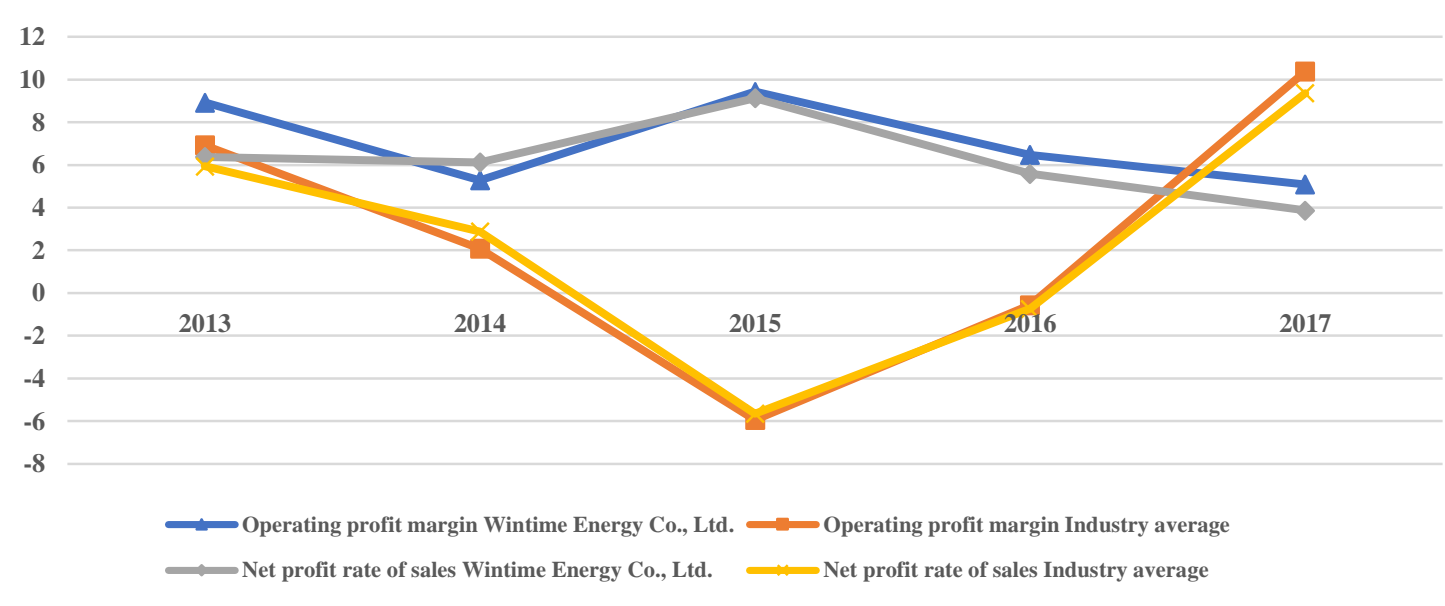

Figure 5 Broken line statistics of main profitability indicators of Wintime Energy Co., Ltd. from 2013 to 2017 (1) (\%)

Broken line statistical chart of main profitability indicators of Wintime

Energy Co., Ltd. from 2013 to 2017 (2) (\%)

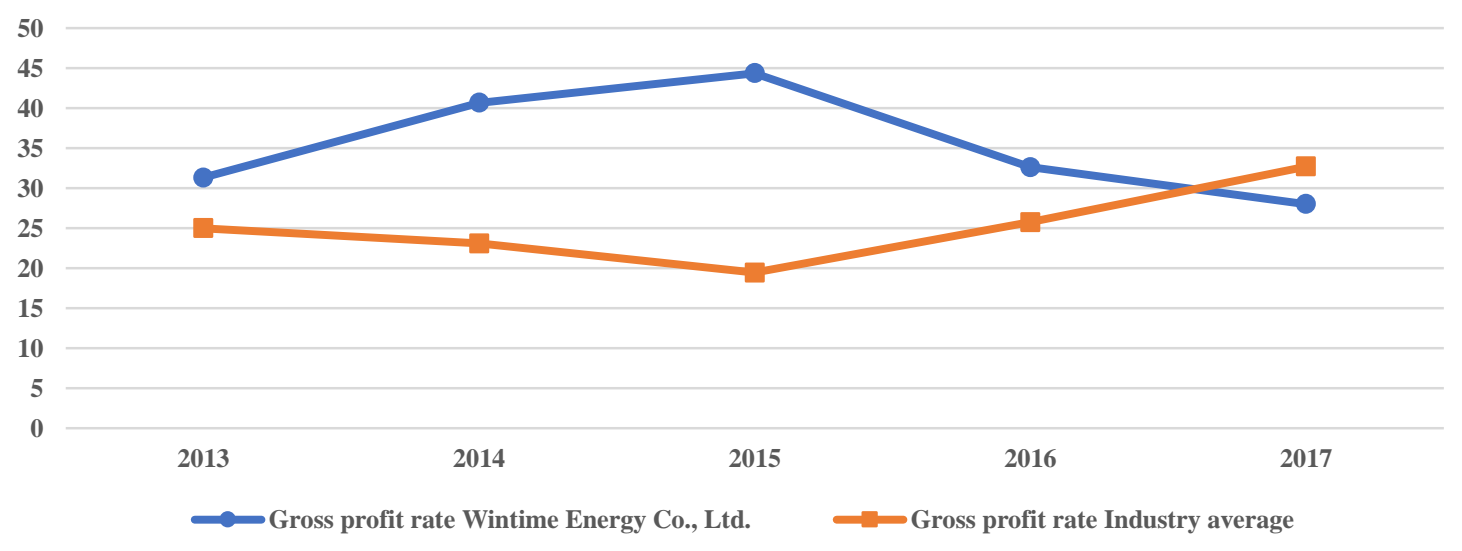

Figure 6 Broken line statistical chart of main profitability indicators of Wintime Energy Co., Ltd. from 2013 to 2017 (2) $(\%)$ 
Although Yongtai coking coal is of good quality, obvious price advantage and relatively high gross profit, the difference is too big compared with the average level of the industry, and its profitability is questionable. The most important asset of coal industry is coal as inventory, and the value of inventory determines the value and profit of enterprise to a large extent. According to the principle of prudence, when faced with uncertain factors, enterprises should make prudent judgment and make provision for impairment when necessary. According to the report data, Wintime Energy Co., Ltd. has obvious signs of underestimating the impairment and bad debt compared with the inventory impairment and the bad debt provision proportion of accounts receivable in the same industry. It can be seen that the recognition of accounts receivable and inventory impairment of Table 4 Z value calculation results of Wintime Energy Co., Ltd. from 2013 to 2017

\begin{tabular}{c|c|c|c|c|c}
\multicolumn{1}{c|}{ Year } & 2013 & 2014 & 2015 & 2016 & 2017 \\
\hline$X_{1}$ & -0.13 & -0.14 & -0.14 & -0.19 & -0.18 \\
\hline$X_{2}$ & 0.03 & 0.03 & 0.02 & 0.02 & 0.02 \\
\hline$X_{3}$ & 0.05 & 0.06 & 0.05 & 0.05 & 0.04 \\
\hline$X_{4}$ & 0.39 & 0.36 & 0.42 & 0.42 & -0.48 \\
\hline$Z$ value & -0.013 & -0.06 & -0.10 & -0.43 & 0.37 \\
\hline
\end{tabular}

Wintime Energy Co., Ltd. is very loose, which greatly increases the amount of assets and net profit in the financial statements of the enterprise, and will cause the false high profitability index.

\subsection{Comparative evaluation of Z-score early warning model results}

\subsubsection{Analysis of Z-score early warning model} industry factors and has a good risk warning effect on enterprises. The calculation results of $Z$ value of Wintime Energy Co., Ltd. by using $\mathrm{Z}_{2}$ model are shown in Table 4:
The revised $Z_{2}$ model minimizes the impact of

According to table 4, the $\mathrm{Z}$ value of Wintime Energy Co., Ltd. showed a fluctuating downward trend from 2013 to 2017, and maintained at a negative value, far less than the critical value of 2.6 in the danger zone. It was in the danger zone for five consecutive years, especially in 2016 , the $\mathrm{Z}$ value dropped from -0.1 to -0.43 , down by 0.33 , and the lowest value was -0.48 in 2017 . This shows that the financial situation of Wintime Energy Co., Ltd.is deteriorating, the financial risk is increasing, and the risk of bond default is aggravating.

To sum up, the analysis results of financial indicators from 2013 to 2017 are consistent with the analysis results of Z-score early warning model. It can be seen that Wintime Energy Co., Ltd. has poor debt paying ability, weak operation ability, poor operation status and high financial risk in recent five years.

\section{ANALYSIS ON THE BOND DEFAULT REASONS OF WINTIME ENERGY CO., LTD.}

\subsection{Macro reasons}

First, coal consumption demand is low. With the slowdown of China's economic development in recent years, the demand of downstream industries such as steel and chemical industry is in a low state, and the demand for coal is decreasing. Secondly, there are structural problems in the coal industry. The inventory of coal enterprises is high, and overcapacity makes the product oversupply. Finally, the tightening of financing channels increases the risk of the bond market. A series of regulatory measures launched in 2018 have limited the financing channels of enterprises. Among them, the new regulation of fixed increase clearly stipulates that the number of shares to be issued shall not exceed $20 \%$ of the total share capital, and the time limit of private additional issuance shall exceed 18 months from the last fundraising. It is a common practice of Wintime Energy Co., Ltd. to increase the fixed amount through the stock market, which undoubtedly tightens the financing channels of Wintime Energy Co., Ltd. .

\subsection{Enterprise's own reasons}

First, in recent years, Wintime Energy Co., Ltd. has been heavily dependent on external financing. The high scale of debt makes the asset liability ratio of Wintime Energy Co., Ltd. basically maintain at a high debt level of more than $70 \%$, with a high proportion of debt and high financing risk. Second, blind expansion brings 
strategic risks. In 2014, Wintime Energy Co., Ltd. began to adjust its industrial structure with a single coal as its main business, and realized the diversified development pattern of comprehensive energy development and emerging investment. As a result, its own resource conditions are difficult to meet the needs of diversified development, and its ability to deal with the overall risk of the market is reduced, which makes it bear a heavy burden.

\subsection{Reasons for rating agencies}

On the one hand, some rating agencies in the credit rating market are lack of standardization and poor selfdiscipline. The payment method of bond issuers is easy to lead to collusion between bond issuers and rating agencies, and even chaos of spending money to buy ratings. On the other hand, there is a lag in rating adjustment" After the substantial default of "cp004" of Wintime Energy Co., Ltd., the rating of Wintime Energy Co., Ltd.was adjusted from "AA +" to "CC" in a short period of time, and the rating was continuously lowered by seven grades, which also shows that the credit rating of Wintime Energy Co., Ltd. was frequently downgraded by united credit .The rating adjustment was lagging behind.

\subsection{Regulatory perspective}

In China, different bonds are supervised by different institutions, and different regulatory agencies have different laws to refer to. For example, the people's Bank of China refers to the law of the people's Bank of China, while the Securities Regulatory Commission manages according to the securities law, which makes different regulatory agencies have different interpretations of access standards for different bonds. In the actual supervision process, there is a lack of unified supervision norms to guide the unified action of various departments, resulting in a gap in the scope of supervision, which reduces the efficiency of bond supervision, which not only hinders the development of the bond market, but also brings inconvenience to bond issuers and investors.

\section{CONCLUSIONS AND SUGGESTIONS}

This paper studies bond default risks through a detailed case study of Wintime Energy Co., Ltd. The research uses financial index analysis and Z-score model to conduct early warning analysis on the financial risk of the company. It analyzes the reasons for its bond default and makes reasonable suggestions on the current bond default phenomenon. It is concluded that there are a few bond default risks which can be mitigated or eliminated by the effort of different stakeholders. More detailed suggestions are discussed as follows.

\subsection{Macro perspective}

We should pay attention to the macro-economic environment and macro-economic policies, especially the environmental protection policies and industrial policies related to the development of coal enterprises, and make timely response measures according to the changes of macro-economic environment. At the same time, we are expected to broaden sales channels, do a good job in marketing plan, market demand forecast and timely adjustment of coal production, so as to improve the business situation of enterprises.

\subsection{Enterprise's own perspective}

We should adjust the capital structure, reduce the ratio of debt financing, choose a reasonable and stable development model, improve the utilization of idle funds, alleviate the financial and default credit pressure to the greatest extent, and reduce the possibility of bond default.

\subsection{From the perspective of rating agencies}

On the one hand, we should make use of the existing industry policies to improve the self-discipline of the environment of the bond rating industry, and form a good bidding and charging mechanism in the industry. On the other hand, we should improve the rating method, adjust the credit rating according to the change of the environment in time, and overcome the lag of rating adjustment, so that the rating agencies can reflect the real level of the bond credit more timely and objectively, and give bond investors a good investment reference.

\subsection{Regulatory perspective}

Unified regulatory body, China's current multi agency regulatory model makes the bond market regulatory vacuum. In order to improve this situation and improve the operational efficiency of the bond market, we need to establish a complete legal system to regulate the bond market [5]. For example, through the establishment and improvement of laws and regulations, we can give the CSRC unified regulatory power, centralize the power of the primary regulatory body and the secondary regulatory body of the bonds, and the CSRC can conduct unified supervision on the bond market, so as to realize the unification from the regulatory body to the regulatory laws and regulations, and improve the regulatory level of corporate bonds.

\section{REFERENCES}

[1] Altman B E L.Discriminant Analysis and the Prediction of Corporate Bankruptcy[J].The Journal of Finance.1968.9.

[2] Ling Zhang,Edward I. Altman,Jerome Yen. Corporate financial distress diagnosis model and 
application in credit rating for listing firms in China[J]. Frontiers of Computer Science in China, 2010,4(2).

[3] Kollar Boris,Weissova Ivana,Siekelova Anna. Quantification of Credit Risk with the Use of CreditMetrics[J]. Procedia Economics and Finance,2015,26.

[4] F. Albert Wang,Ting Zhang. The effect of unfunded pension liabilities on corporate bond ratings, default risk, and recovery rate[J]. Review of Quantitative Finance and Accounting,2014,43(4).

[5] Gao Liu. Risks, problems and Countermeasures in the development of corporate bonds in China [J]. Southern finance, 2017 (04): 58-65 